\title{
EFFECT OF SCARIFICATION AND TEMPERATURE ON SEED Germination Of tWo MEXICAN SPECIES OF MimOSA (LEGUMINOSAE-MiMOSOIDEAE)
}

\author{
Susana Adriana Montaño-Arias ${ }^{1,2,4}$, Sara lucía Camargo-Ricalde ${ }^{2,4}$, Rosaura Grether ${ }^{2}$ \\ y DAVID DÍAZ-PontOnes ${ }^{3}$ \\ 'Doctorado en Ciencias Biológicas y de la Salud \\ ${ }^{2}$ Departamento de Biología \\ ${ }^{3}$ Departamento de Ciencias de la Salud, División de Ciencias Biológicas y de la Salud, \\ Universidad Autónoma Metropolitana-Iztapalapa, México, D.F. México \\ ${ }^{4}$ Corresponding authors: slcr@xanum.uam.mx; arias_susan@hotmail.com
}

\begin{abstract}
It has been considered that Mimosa aculeaticarpa var. aculeaticarpa and M. luisana have the potential to restore temperate and semi-arid environments, respectively. Mature seeds were collected from eight mother plants per taxon to determine the effects of scarification and temperature on seed germination of both taxa, and to define the optimum temperature for germination. To obtain a representative sample of each taxon, seeds with the same weight and size were mixed. Five replicates of 20 seeds each (100 seeds per taxon/temperature, plus the control) were established. The seeds were mechanically scarified and incubated under controlled conditions: 5 to $45^{\circ} \mathrm{C}$ with $5{ }^{\circ} \mathrm{C}$ intervals, and a $12 \mathrm{~h} \mathrm{light} / 12 \mathrm{~h}$ darkness photoperiod. Results showed that scarification and temperature were significant factors in seed germination. In both taxa, germination was epigeal and phanerocotylar. The highest seed germination percentages were obtained when seeds were scarified. $88 \%$ of seeds of M. aculeaticarpa var. aculeaticarpa germinated at $25^{\circ} \mathrm{C}$. Hundred percent of seeds of $M$. luisana germinated at $30^{\circ} \mathrm{C}$. The optimum temperature for germination of seeds of both taxa was established at $25^{\circ} \mathrm{C}$. Mimosa taxa differ in the germination rate: $M$. luisana germinated at 6.6 seeds/day and M. aculeaticarpa var. aculeaticarpa at 3.4 seeds/day. Overall results suggest that, for both taxa, an increase or decrease in temperature will not inhibit seed germination, supporting the recommendation to use these plants for reforestation, as part of environmental restoration projects in temperate and semi-arid Mexican regions.
\end{abstract}

Key words: arid tropical scrub, conservation, restoration, temperate forest.

Resumen: Mimosa aculeaticarpa var. aculeaticarpa y M. luisana son taxa con potencial para la restauración ambiental. Se evaluaron los efectos de la escarificación y la temperatura en la germinación de semillas de ambos taxa y se definió la temperatura óptima de germinación, se colectaron semillas maduras de ocho individuos por especie. Las semillas (igual peso y tamaño) se mezclaron para obtener una muestra compuesta por taxon. Se establecieron cinco repeticiones de 20 semillas por taxon (100 semillas por taxon, por temperatura, más el control). Las semillas fueron escarificadas mecánicamente, realizando un corte en el extremo opuesto al eje del embrión e incubadas en un gradiente de 5 a $45^{\circ} \mathrm{C}$, con intervalos de $5{ }^{\circ} \mathrm{C}$ y un fotoperíodo de $12 \mathrm{~h}$ luz/12h oscuridad. Los resultados indican que la escarificación y la temperatura son factores significativos para la germinación de las semillas. En ambos taxa, la germinación fue epígea y fanerocotilar. Los mayores porcentajes de germinación se obtuvieron cuando las semillas fueron escarificadas. Mimosa aculeaticarpa var. aculeaticarpa logró el $88 \%$ de germinación a $25^{\circ} \mathrm{C}$; mientras que $M$. luisana alcanzó $100 \%$ a $30^{\circ} \mathrm{C}$; sin embargo, para ambos taxa la temperatura óptima de germinación fue de $25^{\circ} \mathrm{C}$. La tasa de germinación difiere, en $M$. luisana se registraron 6.6 semillas/día; mientras que en M. aculeaticarpa var. aculeaticarpa sólo 3.4 semillas/día. Los resultados sugieren que ante un incremento o decremento en la temperatura, la germinación de las dos especies estudiadas no será inhibida; por lo tanto, se apoya la recomendación del uso de ambas especies en reforestación como parte de proyectos de restauración ambiental en regiones templadas y semiáridas de México.

Palabras clave: bosque templado, conservación, matorral xerófilo; restauración.

n Mexico, species of Mimosa L. (Leguminosae-Mimosoideae) have attracted attention due to their multiple uses, their ability to survive in harsh environments, to resprout after having been cut or burnt, because the genus has many ecological, economic, and cultural values (Camargo-Ricalde et al., 2001). Mimosa comprises ca. 530 species in the world, and it is one of the three largest genera of Mimosoideae, along with Acacia and Inga (Simon et al., 2011). 
After Brazil, Mexico is the second diversification center of Mimosa, being the most diverse genus of the subfamily with ca. 110 species, $60 \%$ endemic to the country, many of them occurring as dominant or co-dominant elements in arid ecosystems, widely distributed in tropical vegetation, and few species growing in temperate forests (Grether et al., 1996; Camargo-Ricalde et al., 2002). Within arid and semi-arid environments, some Mimosa species are resource-island formers, enriching the soil with organic matter and nutrients (Camargo-Ricalde et al., 2002, 2010a), and as reservoirs of arbuscular mycorrhizal fungal spores (Camargo-Ricalde and Dhillion, 2003), and nitrogen-fixing bacteria (CamargoRicalde et al., 2010a, b). In addition, the nurse effect is very clear between Mimosa luisana Brandegee and Neobuxbaumia tetetzo (F.A. C.Weber ex K.Schum) Backeberg, a columnar cactus endemic to Mexico (Valiente-Banuet et al., 1991; Valiente-Banuet and Ezcurra, 1991). Hence, some Mimosa species are considered potentially useful for ecological restoration projects (Dhillion et al., 2004; MorenoCalles and Casas, 2010; Pavón et al., 2011).

As a first step, it is known that seeds of some Mimosa species are able to germinate in a wide range of temperatures (De Souza-Araújo and De Castro-Andrade, 1983; CamargoRicalde et al., 2004; Pavón et al., 2011), and that scarification increases the percentage of germination (Ferreira et al., 1992; Camargo-Ricalde and Grether, 1998; Camargo-Ricalde et al., 2004; González-Castañeda et al., 2004; Silveira and Fernandes, 2006; Leal and Biondi, 2007; Chahuan and Johnson, 2008; Pavón et al., 2011; Gehan-Jayasuriya et al., 2013). However, it is not yet possible to generalize about how seeds will respond to both seed scarification and temperature fluctuation because only $5 \%$ of the species of $\mathrm{Mi}$ mosa have been studied around the world. For the Mexican Mimosa, seed germination has merely been studied in 13 species occurring in arid ecosystems (i.e. Camargo-Ricalde et al., 2004, Pavón et al., 2011) and only one from temperate forests (Martínez-Pérez et al., 2006).

Hence, and under the assumption that species are adapted to the environments where they have evolved, arid and semiarid ecosystem species will be able to germinate at higher and more extreme temperatures than temperate ecosystem species. Therefore, the aims of this study were: (i) To determine the effects of scarification and temperature on seed germination percentage, germination rate and saturation rate; and (ii) To define the optimum temperature for seed germination, of two Mimosa taxa occurring in two contrasting ecosystems: Mimosa aculeaticarpa var. aculeaticarpa Ortega (temperate forest, endemic to Mexico) and M. luisana (arid tropical scrub, narrow endemic to Mexico).

\section{Materials and Methods}

Experimental design. Mature fruits of M. aculeaticarpa var. aculeaticarpa and M. luisana were collected during the maximum productivity season of each taxon (November and October, respectively), from eight different mother plants with similar height and foliage cover. Fruit harvesting was random, spanning the entire area of the canopy per plant.

Mimosa aculeaticarpa var. aculeaticarpa was collected from a temperate forest, in the Municipality of Tiripetío, State of Michoacán, $19^{\circ} 58.218^{\prime} \mathrm{N}, 101^{\circ} 31.664^{\prime} \mathrm{W}$, at $1,950 \mathrm{~m}$ a.s.l., and M. luisana from an arid tropical scrub, in the Valley of Tehuacán, State of Puebla, $18^{\circ} 15^{\prime} 23.7^{\prime \prime} \mathrm{N}$, $97^{\circ} 09^{\prime} 03.3^{\prime \prime} \mathrm{W}$, at 2,232 $\mathrm{m}$ a.s.l. Voucher specimens were deposited at the Herbario Metropolitano (UAMIZ), Universidad Autónoma Metropolitana-Iztapalapa.

Seed characterization and treatments prior to sowing. After collection, seeds were removed from the fruits. Approximately, 10,000 seeds, per species, were obtained and stored in plastic containers, at room temperature $\left(20^{\circ} \mathrm{C}\right)$, in Mexico City. For two weeks, bruchids (Insecta, Coleoptera) emerging from the seeds were collected and fixed in FAA for identification.

Since seed size and weight can influence the rate of germination (Matilla, 2004; Skogen et al., 2010), 3,600 healthy mature seeds per taxon, were characterized. The evaluated variables were: length, width and thickness, as well as seed weight. Seed size was measured with a digital vernier caliper (Absolute Digimatic, CD-6"CS), and seed weight was determined individually using an analytical balance with $10^{-4} \mathrm{~g}$ resolution (Adventurer, Ohaus, Melrose, USA). Healthy seeds, of both taxa, with a similar range of size and weight, were mixed to obtain a combined sample. It is important to mention that for assuring the adequate development of the whole assay, the range of seed size and weight was chosen in terms of the minimum number of seeds needed for it.

Germination assays under laboratory conditions. Legume seeds are known to have physical dormancy (Baskin, 2003; Van Assche et al., 2003; Venier et al., 2012; Gehan-Jayasuriya et al., 2013), as Mimosa species (Martínez-Pérez et al., 2006; Gehan-Jayasuriya et al., 2013). Prior to any assay, all Mimosa seeds were washed with commercial detergent ( $3 \mathrm{~g} / 100 \mathrm{ml}$ water/3 $\mathrm{min}$ ) (Camargo-Ricalde and Grether, 1998). Seeds were mechanically scarified: the seed coat was cut at the side opposite to the embryo's axis in order to avoid damage. Germination assays took place in an incubator (Conviron T 38/Lb/AP), using trays $(30 \times 15 \times 20 \mathrm{~cm})$, with agar $(3 \%)$ as substrate. A temperature gradient with nine intervals of $5{ }^{\circ} \mathrm{C}$ each (from 5 to $45^{\circ} \mathrm{C}$ ), and a photoperiod of $12 \mathrm{~h}$ light $/ 12 \mathrm{~h}$ darkness was set.

For every thermal treatment, five replicates of 20 scarified seeds each (100 seeds per taxon, 1,800 seeds in total), as well as five replicates of 20 unscarified seeds each as control (100 seeds per taxon, 1,800 seeds in total) were established. Seeds were considered as germinated when the radicle reached $1 \mathrm{~mm}$ in length (Bewley and Black, 1994). All the assays continued for 30 days. 
To analyze the effect of temperature fluctuations in relation to the seed germination behavior of plants, diverse authors (i.e. Piedrahita-Cardona 1997, 1998; Enríquez-Peña et al., 2004; Weng and Hsu, 2006; Pavón et al., 2011) consider the parameters listed below, which will be used, as well, for the Mimosa taxa studied here:

Total Percentage of Germination (PG).- it is defined as the percentage of the total germination at the end of the assay.

Half Germination Rate $\left(\mathrm{G}_{50}\right)$.- it is the number of days, after sowing, needed to reach $50 \%$ of germination, and it was estimated by interpolating the day before and the day after in which $50 \%$ of the total seed germination was obtained.

Germination Rate (GR).- it is defined as the correlation between the number of germinated seeds and the germination time: $\mathrm{GR}=\Sigma\left(\mathrm{n}_{\mathrm{i}}\right) / \mathrm{t}$, where $\mathrm{n}_{\mathrm{i}}=$ number of germinated seeds in one day (i), $\mathrm{t}=$ time from sowing until the last seed germinates.

Saturation Rate (SR).- it is defined as the time for germination in relation to the germination percentage: $\mathrm{SR}=$ $\Sigma\left(\mathrm{n}_{\mathrm{i}} \mathrm{t}_{\mathrm{i}}\right) / \mathrm{N}$, where $\mathrm{n}_{\mathrm{i}}=$ number of germinated seeds in one day (i); $t_{i}=$ number of days after sowing, $\mathrm{N}=$ total number of seeds sown.

Optimum Temperature (OT).- it was calculated as the average of all temperatures, weighted with the total seed germination percentage, at each temperature (Olff et al., 1994).

Statistical analyses. Seed weight was compared between taxa using a $t$-student test $(P<0.05)$. Homogeneity of variance was examined for all temperature treatments (Levene's test, $P<0.05$ ). When homogeneity of variance was found, a one-way ANOVA was used to analyze the intraspecific variation within the germination percentages and between control and scarified seeds, and a two-way ANOVA to examine the interspecific variation within the germination percentages, where the taxa and the temperatures were the variables (ANOVA, $P<0.05$ ). A multiple comparison test was employed (Tukey's HSD, $P<0.05$ ) to form groups. In $M i$ mosa aculeaticarpa var. aculeaticarpa, the homogeneity of variance of $S R$ was not found; therefore, the non-parametric Kruskal-Wallis test was used $(P<0.05)$, and medians were compared by the Mann-Whitney test $(P<0.05$, Sokal and Rohlf, 1995). All analyses were performed with the NCSS Software (Hintze, 2001).

\section{Results}

Seed size, weight, and production. The two studied Mimosa taxa produce numerous seeds of variable weight and size. When comparing the weight of seeds between both taxa and within each taxon, no significant differences were showed $(t$ $=0.7442, P>0.05)$. In this sense, no significant differences were found, when comparing the size between and within both taxa; though, M. aculeaticarpa var. aculeaticarpa seeds were the biggest (Table 1).
Not all collected seeds were healthy; many of them were infested by bruchids (Insecta, Coleoptera). The mean percentage of infestation was $11.9 \%$ for M. aculeaticarpa var. aculeaticarpa, and $48.7 \%$ for M. luisana (Table 1). In the case of $M$. aculeaticarpa var. aculeaticarpa, two species of seed predator bruchids were identified, Acanthoscelides chiricahuae (Fall) and A. mexicanus (Sharp). Mimosa luisana seeds were infested by three species, two belonging to genus Acanthoscelides (Acanthoscelides mexicanus and A. chiricahuae) and one to genus Stator [Stator pruininus (Horn)].

Scarification effect on the total percentage of seed germination $(P G)$. The two Mimosa taxa showed both epigeal and phanerocotylar germination, which started the first day after sowing. In both taxa, germination was stimulated by scarification (Figures 1-3; Table 2). The PG of unscarified seeds was low and slow. Scarified seeds registered a significantly higher PG $(F=143.88, P<0.001$; Table 2$)$. Scarified seeds of M. aculeaticarpa var. aculeaticarpa germinated 57 times faster than those of M. luisana. In the case of Mimosa luisana, unscarified seeds germinated five times faster than those of M. aculeaticarpa var. aculeaticarpa (Figures 1-3). Although these data were not statistically significant, seeds of Mimosa luisana tended to germinate in greater numbers than those of M. aculeaticarpa var. aculeaticarpa (Table 2).

Temperature effect on total seed germination percentage $(P G)$. The two-way ANOVA analysis showed a significant effect of the two factors, taxon and temperature, on the PG (Tables 3,4). The lowest germination percentage of both taxa was recorded at $5{ }^{\circ} \mathrm{C}$ (Figures 1-3), differing significantly from the other temperature ranges $(F=33.03$ and $F=18.63$; both with $P<0.005$, respectively). The highest PG (88\%) was recorded at $25^{\circ} \mathrm{C}$ in M. aculeaticarpa var. aculeaticarpa $(F=33.03 ; P<0.005)$; although, $88 \%$ of

Table 1. Mimosa taxa mature seed size, weight, production, and percentage of infested and non-infested seeds by bruchids (Insecta, Coleoptera).

\begin{tabular}{cccc}
\hline \multicolumn{2}{c}{$\begin{array}{c}\text { Variables / } \\
\text { Taxon }\end{array}$} & $\begin{array}{c}\text { M. aculeaticarpa } \\
\text { var. aculeaticarpa }\end{array}$ & M. luisana \\
\hline Size $(\mathrm{mm})$ & Length & $3.0-4.4$ & $2.6-3.5$ \\
& Width & $2.0-3.0$ & $1.8-2.4$ \\
& Thickness & $0.01-0.02$ & $2.0-2.7$
\end{tabular}

\begin{tabular}{lcc}
\hline $\begin{array}{l}\text { Mature seed } \\
\text { weight }(\mathrm{gr}) \\
\text { (Mean } \pm \mathrm{SE} \text { ) }\end{array}$ & $0.008 \pm 0.0004^{\mathrm{a}}$ & $0.00864 \pm 0.0006^{\mathrm{a}}$ \\
\hline Production (number) & 9,891 & 12,276 \\
\hline $\begin{array}{l}\text { Infested seeds (\%) } \\
\text { Non-infested seed } \\
\text { production (\%) }\end{array}$ & 11.9 & 48.7 \\
\hline
\end{tabular}

Values followed by the same letter are not significantly different $(P<0.05)$. 

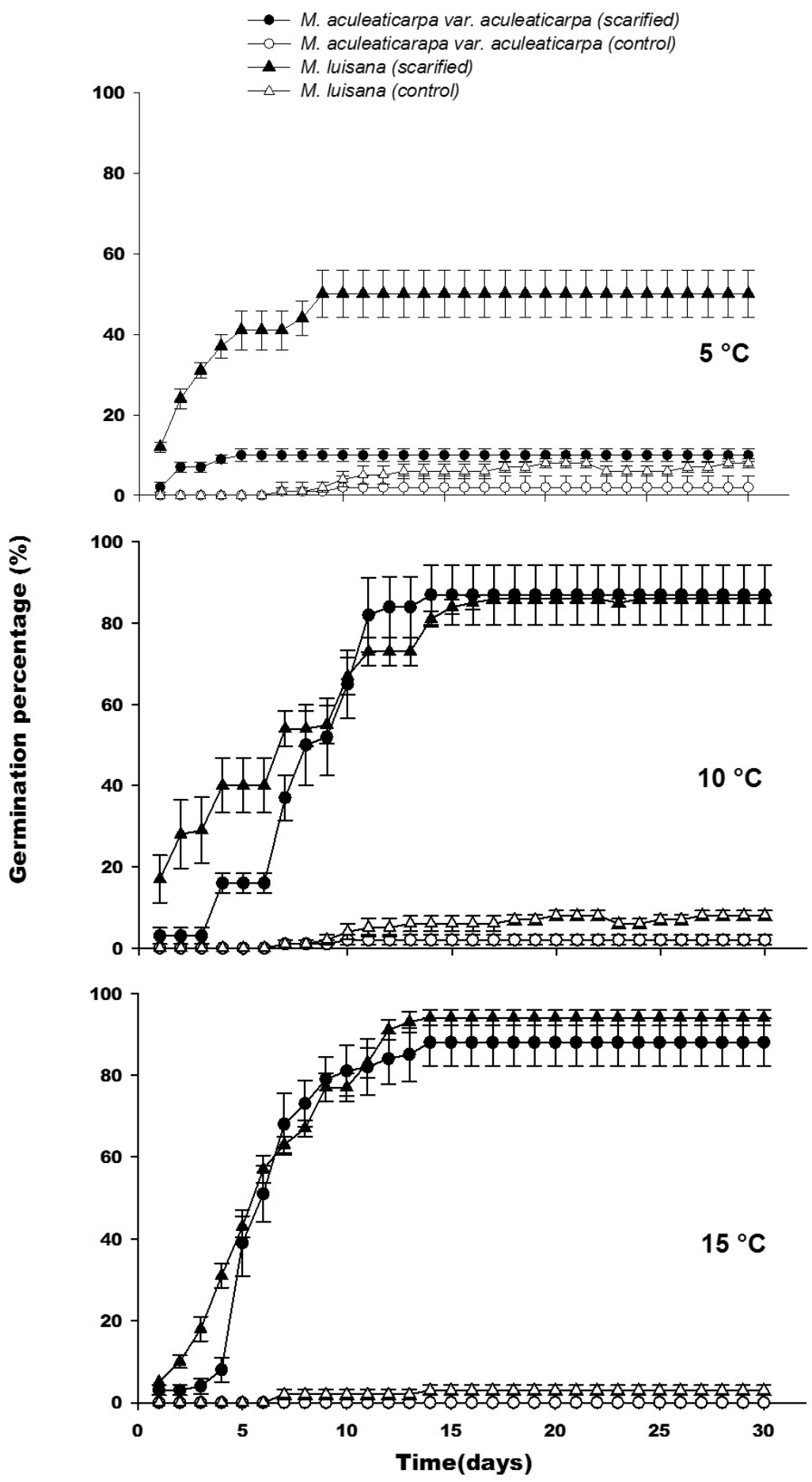

Figure 1. Seed Germination Percentage (PG $- \pm \mathrm{SE}$ ) of two Mimosa taxa along a temperature gradient $5-15^{\circ} \mathrm{C}$.

germination was also achieved at $15^{\circ} \mathrm{C}$, but seeds required more days $(\mathrm{SR}=5)$ to reach this percentage (Table 4). In $M$. luisana, the highest percentage of germination $(100 \%)$ was reached at $30^{\circ} \mathrm{C}$; whereas, at higher or lower temperatures, the PG decreased (Figure 2; Table 4).

The effect of the interaction between the two factors, taxon and temperature, on the PG was significant $(P<0.001)$, indicating that the germinative response to temperature depended on the taxon. There was a decrease in the PG at extreme temperatures, 5 and $45^{\circ} \mathrm{C}$ (Figures 1-3).

In relation to the half of seed germination $\left(\mathrm{G}_{50}\right)$, the taxon factor presented an interaction with the temperature factor $(P<0.001$, Table 3$)$, indicating that seed germination response $\left(\mathrm{G}_{50}\right)$ to temperature depended on the taxon. 


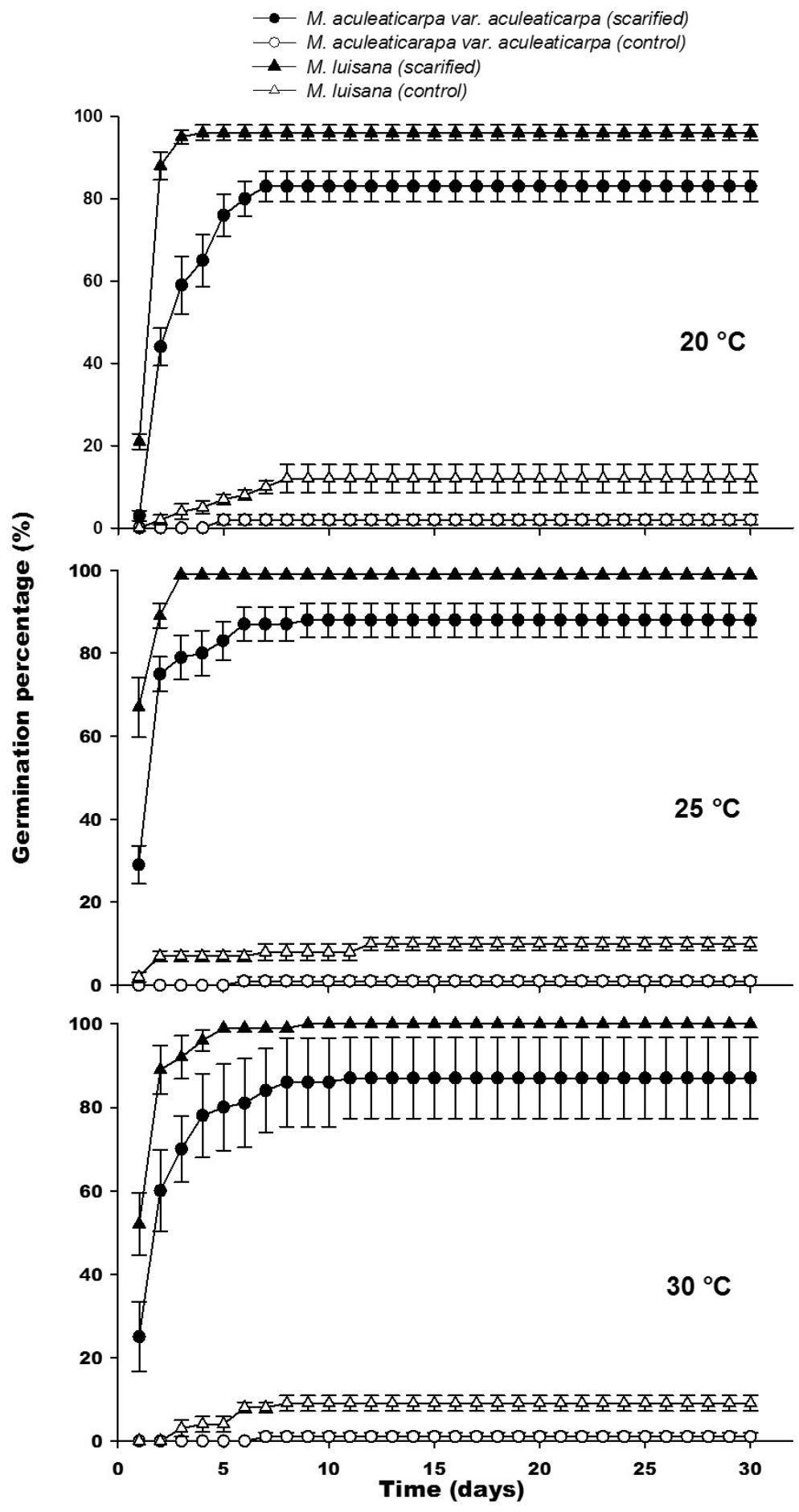

Figure 2. Seed Germination Percentage (PG - \pm SE) of two Mimosa taxa along a temperature gradient $20-30{ }^{\circ} \mathrm{C}$.

Although at $20^{\circ} \mathrm{C}$, M. aculeaticarpa var. aculeaticarpa reached $50 \%$ of seed germination on the second day after sowing, at 25 and $30{ }^{\circ} \mathrm{C}$, the $50 \%$ of seed germination was exceeded on the second day after sowing. However, more days were needed to reach $50 \%$ of germination at temperatures below $20{ }^{\circ} \mathrm{C}$ and above $35^{\circ} \mathrm{C}$. Moreover, only $35 \%$ of seed germination was reached at $45^{\circ} \mathrm{C}$. In the case of $M$. luisana, $50 \%$ of seed germination was attained at $30{ }^{\circ} \mathrm{C}$, the first day after sowing, and this percentage was exceeded at temperatures of 25,35 , and $40{ }^{\circ} \mathrm{C}$; however, the total germination percentage decreased to less than 27 $\%$ at $45^{\circ} \mathrm{C}$ (Figures $1-3$ ).

Furthermore, the results showed that seeds of $M . a c u$ leaticarpa var. aculeaticarpa and M. luisana germinated 
Table 2. Effect of seed scarification on the percentage of germination of two taxa of genus Mimosa.

\begin{tabular}{lll}
\hline Taxon & \multicolumn{2}{c}{ Germination (\%) } \\
\cline { 2 - 3 } & $\begin{array}{l}\text { Unscarified } \\
\text { (Mean } \pm \text { SE) }\end{array}$ & $\begin{array}{l}\text { Scarified } \\
\text { (Mean } \pm \text { SE) }\end{array}$ \\
\hline $\begin{array}{l}\text { M. aculeaticarpa var. } \\
\text { aculeaticarpa }\end{array}$ & $1.22 \pm 0.22^{\mathrm{Aa}}$ & $70.0 \pm 8.35^{\mathrm{Bb}}$ \\
M. luisana & $6.33 \pm 1.46^{\mathrm{Aa}}$ & $79.6 \pm 8.31^{\mathrm{Bb}}$ \\
\hline
\end{tabular}

Values followed by the same letter are not significantly different in columns (lower case) and rows (upper case), $P<0.05$.

along the gradient of temperature $\left(5-45^{\circ} \mathrm{C}\right)$. However, the optimum temperature (OT) for seed germination for both taxa was determined at $25^{\circ} \mathrm{C}$ (Table 4).

Temperature effect on the germination rate $(G R)$. The Germination Rate (GR) was significantly affected by the taxon and the temperature factors $(F=9.9 ; P<0.001$, Figure 4 A, Table $3)$. GR increased significantly when the temperature reached $30{ }^{\circ} \mathrm{C}$. In average, three seeds of M. aculeaticarpa var. aculeaticarpa germinated/day at $25^{\circ} \mathrm{C}$; whereas, six seeds of $\mathrm{M}$. luisana germinated/day at the same temperature. However, the GR of seeds of both, M. aculeaticarpa var. aculeaticarpa and of M. luisana, decreased at temperatures above 30 and $35^{\circ} \mathrm{C}$, respectively. In the case of M. aculeaticarpa var. aculeaticarpa, the GR increased at $45{ }^{\circ} \mathrm{C}$; although, only $35 \%$ of seed germination was recorded (Figure 4A).

Regarding the saturation rate (SR), a significant interaction between the two factors, taxon and temperature, was also observed ( $F=4.38 ; P<0.001$, Table 3$)$, indicating that the SR depended on the taxon. Mimosa aculeaticarpa var. aculeaticarpa required numerous days to reach the PG; whereas, $M$. luisana required even more days to reach it at $15^{\circ} \mathrm{C}$ (Figure 4B).

\section{Discussion}

The overall results obtained in this study are relevant under the context of possible temperature and precipitation fluctuation. In this case, this study tries to elucidate the influence of both temperature change and seed scarification on Mimosa seeds germination:

Table 3. Two-way ANOVA to analyze the effect of the temperature on the percentage of seed germination of two taxa of genus Mimosa.

\begin{tabular}{lccccc}
\hline & & $\begin{array}{c}\text { Germination } \\
(\mathbf{\%})\end{array}$ & $\mathbf{G}_{50}(\mathbf{d})$ & $\begin{array}{c}\text { GR } \\
(\mathbf{s e e d s} / \mathbf{d})\end{array}$ & $\mathbf{S R}(\mathbf{d})$ \\
& $\mathbf{D F}$ & $\boldsymbol{F}$ & $\boldsymbol{F}$ & $\boldsymbol{F}$ & $\boldsymbol{F}$ \\
\hline Taxon $(\mathrm{S})$ & 1 & $20.65^{\text {ns }}$ & $19.25^{* * *}$ & $12.54^{* * *}$ & $9.27^{* *}$ \\
Temperature $(\mathrm{T})$ & 8 & $50.74^{\text {ns }}$ & $49.95^{* * *}$ & $17.71^{* * *}$ & $68.04^{* * *}$ \\
$\mathrm{~S} \times \mathrm{T}$ & 8 & $3.38^{* * *}$ & $3.62^{* * *}$ & $9.92^{* * *}$ & $4.38^{* * *}$ \\
\hline
\end{tabular}

$\mathrm{G}_{50}=$ Half Germination Rate; GR=Germination Rate; SR=Saturation Rate; ns=not significative; ${ }^{* *} P<0.01 ;{ }^{* * *} P<0.001$
Table 4. Total Percentage of seed Germination (PG) and Saturation Rate (SR) of two taxa of genus Mimosa under different temperatures, in a laboratory assay.

\begin{tabular}{|c|c|c|c|}
\hline $\begin{array}{c}\text { Temperature } \\
{ }^{\circ} \mathrm{C}\end{array}$ & $\begin{array}{l}\text { Parameter/ } \\
\text { Taxon }\end{array}$ & $\begin{array}{l}\text { M. aculeaticarpa } \\
\text { var. aculeaticarpa } \\
\text { (Mean } \pm \text { SE) }\end{array}$ & $\begin{array}{c}\text { M. Iuisana } \\
\text { (Mean } \pm \text { SE) }\end{array}$ \\
\hline \multirow[t]{2}{*}{5} & PG (\%) & $10 \pm 1.58^{\mathrm{Ab}}$ & $50 \pm 5.92^{\mathrm{Bb}}$ \\
\hline & SR & 1 & 1 \\
\hline \multirow[t]{2}{*}{10} & PG (\%) & $87 \pm 7.34^{\mathrm{Aa}}$ & $86 \pm 1^{\mathrm{Aa}}$ \\
\hline & SR & 7 & 5 \\
\hline \multirow[t]{2}{*}{15} & PG (\%) & $88 \pm 5.83^{\mathrm{Aa}}$ & $94 \pm 1.87^{\text {Аа }}$ \\
\hline & SR & 5 & 6 \\
\hline \multirow[t]{2}{*}{20} & PG (\%) & $83 \pm 3.74^{\mathrm{Aa}}$ & $96 \pm 1.87^{\mathrm{Aa}}$ \\
\hline & $S R$ & 3 & 2 \\
\hline \multirow[t]{2}{*}{25} & PG (\%) & $88 \pm 4.06^{\mathrm{Aa}}$ & $99 \pm 1^{\mathrm{Aa}}$ \\
\hline & $S R$ & 2 & 1 \\
\hline \multirow[t]{2}{*}{30} & PG (\%) & $87 \pm 9.69^{\mathrm{Aa}}$ & $100 \pm 0^{A a}$ \\
\hline & SR & 2 & 1 \\
\hline \multirow[t]{2}{*}{35} & PG (\%) & $72 \pm 8.30^{\mathrm{Aa}}$ & $81 \pm 4.30^{\text {Аа }}$ \\
\hline & $S R$ & 2 & 1 \\
\hline \multirow[t]{2}{*}{40} & PG (\%) & $69 \pm 7.31^{\mathrm{Aa}}$ & $84 \pm 5.09^{\mathrm{Aa}}$ \\
\hline & SR & 3 & 1 \\
\hline \multirow[t]{2}{*}{45} & PG (\%) & $35 \pm 6.12^{\mathrm{Ab}}$ & $27 \pm 1.22^{\mathrm{Ab}}$ \\
\hline & $S R$ & 1 & 1 \\
\hline $\begin{array}{c}\text { Optimum } \\
\text { Temperature }\left({ }^{\circ} \mathrm{C}\right)\end{array}$ & & 25 & 25 \\
\hline
\end{tabular}

Values followed by the same letter are not significantly different in columns (lower case), and a Tukey HSD to analyze the effect of temperature on the percentage of seed germination (upper case), $\mathrm{P}<0.05$.

Seed size, weight and production. Mature Mimosa seeds showed a significant size and weight variation even coming from the same mother plant. Both the small size of the seeds and their high production are intrinsic characteristics that lead to potentially more competitive plants, such as Mimosa tenuiflora (Willd.) Poir. (Camargo-Ricalde and Grether, 1998) and Mimosa pigra L., which are considered as pioneer or invasive species (Creager, 1992; Lonsdale, 1999).

On the other hand, predation of Mimosa seeds by bruchids (Insecta, Coleoptera), regardless of the size, could reduce their potential germination (Fontúrbel, 2002; Romero-Nápoles et al., 2005). In this study, the percentages of infested seeds were consistent with those reported by OrozcoAlmanza et al. (2003) and Camargo-Ricalde et al. (2004), who found that the species of Mimosa had a high percentage of bruchid-infested seeds (30-75\%), reducing the number of viable seeds and, consequently, the number of seedlings for posterior recruitment.

In this study, seeds of $M$. luisana were infested by three different bruchid species; this Mimosa species had the highest percentage of parasitized seeds (48\%), as well as the highest GR; meanwhile, M. aculeaticarpa var. aculeaticarpa registered the presence of two bruchid species, which infested $11 \%$ of the seeds, showing a lower percentage of 


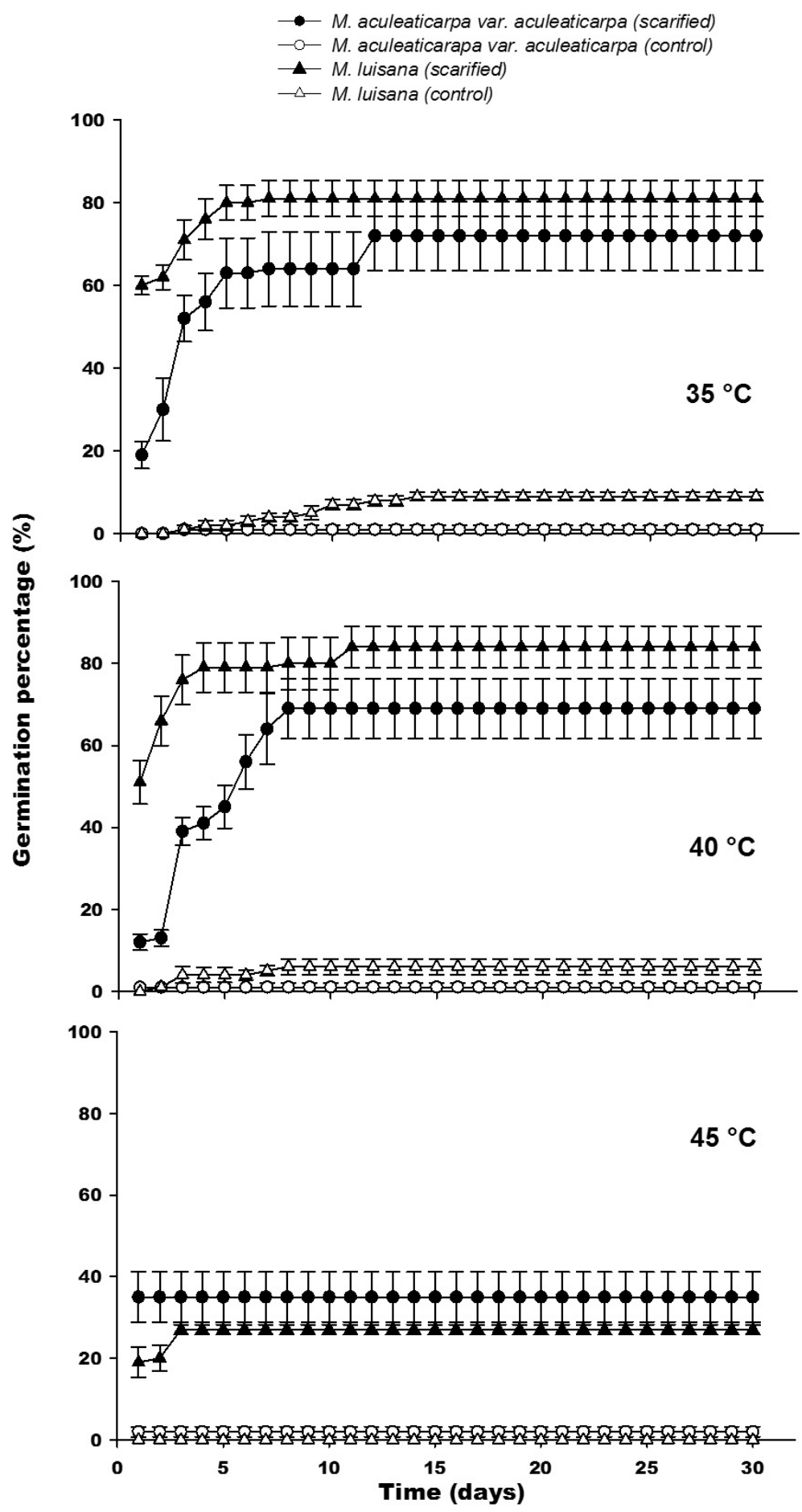

Figure 3. Seed Germination Percentage (PG - \pm SE) of two Mimosa taxa along a temperature gradient $35-45^{\circ} \mathrm{C}$.

seed germination (PG), and suggesting that the presence of more than one bruchid species per plant, may be related to a reproductive strategy (Westoby et al., 1992): a high percentage of bruchid-infestation leads to a high GR. It is possible that in nature, bruchids act as the "natural" seed mechanical scarificators, as it happens in other plant species with a hard seed coat (Takakura, 2002).
Effect of seed scarification on germination. In general, legumes produce seeds with a waterproof coat that causes physical dormancy (Auld, 1996; Lopez et al., 1999; Van Klinken and Flack, 2005), which restricts seed germination under natural conditions (D'Aubeterre et al., 2002). According to Lonsdale (1993), Gehan-Jayasuriya et al. (2013), and Van Klinken and Goulier (2013), seeds of Mi- 
- M. aculeaticarpa var. aculeaticarpa (scarified)

- - M. aculeaticarapa var. aculeaticarpa (control)

- M. luisana (scarified)

$\backsim$ M. luisana (control)
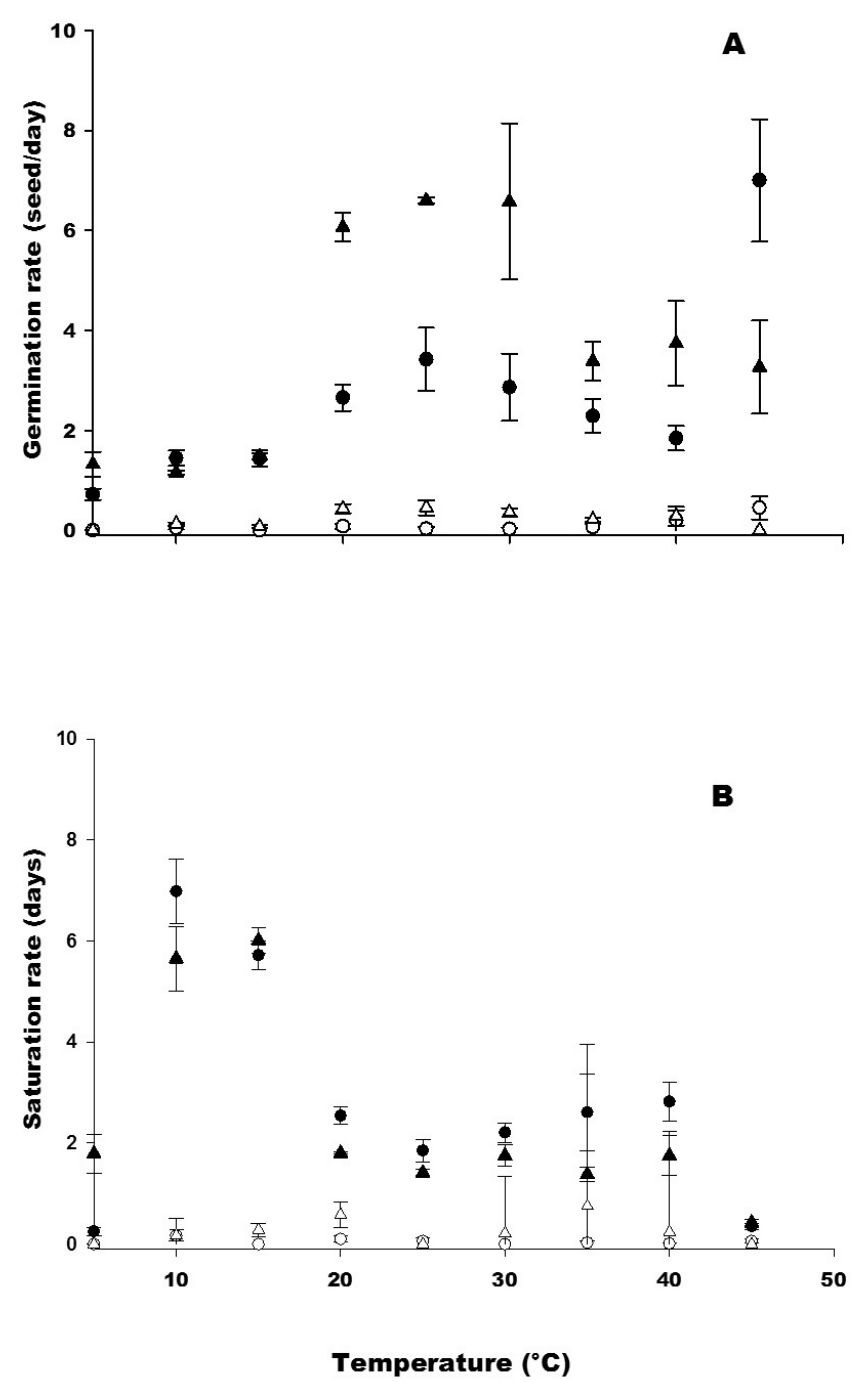

Figure 4. A. Germination Rate (GR - $\pm \mathrm{SE}$ ) of two Mimosa taxa along a temperature gradient; B. Saturation Rate (SR - \pm SE) of two Mimosa taxa along a temperature gradient.

mosa species present physical dormancy and, because the seed coat has one or more impermeable layers of palisade cells, a physiological dormancy is also possible (Baskin et $a l ., 2000)$. Therefore, scarification is necessary to promote seed germination (Camargo-Ricalde and Grether, 1998; Gehan-Jayasuriya et al., 2013). Different seed scarification methods have been documented for Mimosa species (De Souza-Araújo and De Castro-Andrade, 1983; Camargo-Ricalde and Grether, 1998; Martínez-Pérez et al., 2006; Silveira and Fernandes, 2006). However, De Souza-Araújo and De Castro-Andrade (1983), Camargo-Ricalde and Grether (1998), González-Castañeda et al. (2004), Mar-
tínez-Pérez et al. (2006), Chauhan and Johnson (2008), and Gehan-Jayasuriya et al. (2013), have demonstrated that mechanical scarification is the most appropriate technique for breaking seed dormancy of Mimosa species, since mechanically scarified seeds are able to reach the highest germination rates (GR) in comparison to other methods that, positively, damage the embryo and seedling development (i.e. chemical scarification, heat shock, etc.). In this study, mechanically scarified seeds reached high germination percentages (over $70 \%$ ) for both taxa; while, unscarified seeds only achieved 0-12\%. In nature, even if seed germination is low, Mimosa seed scarification occurs by different mechanisms such as changes in daily temperature, incomplete predation by insects as bruchids (Orozco-Almanza et al., 2003; Camargo-Ricalde et al., 2004), damage caused by soil microorganisms, abrasion by soil particles and fire (Baskin et al., 1998; Taylor, 2005), and animal ingestion (i.e. goats, Baraza and Valiente-Banuet, 2008; Giordani, 2008).

However, it is important to mention that control seeds (unscarified seeds) should not be manipulated because the seed coat could be damaged, biasing the results. For instance, Martínez-Pérez et al. (2006) soaked control seeds of four species, including $M$. aculeaticarpa, in water $/ 24 \mathrm{~h}$, reaching $c a$. $60 \%$ germination; almost the same germination behavior as the treated seeds from this study. Thus, control seeds should not be manipulated in any way.

Different assays (i.e. Camargo-Ricalde and Grether, 1998; Martínez-Pérez et al., 2006; Leal and Biondi, 2007) confirm that Mimosa species have fast seed germination, which takes place within the first-fourth day after sowing; however, germination rate (GR) is related to temperature. This characteristic is also intrinsic to pioneer and invasive species (Lonsdale, 1999), and an important feature for plants with ecological restoration potential such as $M$. luisana (Camargo-Ricalde et al., 2004) and Mimosa aculeaticarpa Ortega var. biuncifera (Benth.) Barneby (Pavón et al., 2011).

Temperature effects on seed germination. Mimosa is a neotropical genus (Barneby, 1991; Simon et al., 2011), growing in places where temperature oscillates between 0 and $35^{\circ} \mathrm{C}$ (Cavalcante and Perez, 1995); temperatures that are consistent with this and other studies around the world (i.e. Moreno-Casasola, 1973; Parra, 1984; Creager, 1992; Ferreira et al., 1992; Camargo-Ricalde and Grether, 1998; Camargo-Ricalde, 2000; Ursulino-Alves et al., 2002; Orozco-Almanza et al., 2003; Camargo-Ricalde et al., 2004; Rivera-Aguilar et al., 2005; Silveira and Fernandes, 2006; Cruz-Medina and Orozco-Almanza, 2010), which have defined ranges and optimum seed germination temperatures of 25 Mimosa species. Hence, Mimosa seeds are able to germinate between 0 and $45^{\circ} \mathrm{C}$; though, the optimum temperature (OT) registered for the two taxa studied here is $25^{\circ} \mathrm{C}$.

In this context, it is important to note that Cavalcante 
and Perez (1995) suggested that tropical species can tolerate high temperatures, usually $\geq 35^{\circ} \mathrm{C}$. On the other hand, when seeds were exposed to cold temperatures $\left(\leq 5^{\circ} \mathrm{C}\right)$, germination took place since Mimosa species did not slow their metabolic rate (Hendricks and Taylorson, 1976).

In general, in Mimosa species, temperature is not a limiting factor for seed germination, showing, as well, a fast GR, a high PG, and a fast growth (Camargo-Ricalde and Grether, 1998). These characteristics may explain why Mimosa species may be dominant or co-dominant elements within the plant communities where they occur; for instance, within arid and semi-arid ecosystems (Camargo-Ricalde et al., 2002). Since ecosystems could expand or contract in reaction to plant species tolerance to an increase or decrease in temperature, the response of seed germination to scarification and temperature fluctuation is important to determine (Parmesan and Yohe, 2003). In this case, as both taxa of Mimosa are able to germinate from 5 to $45{ }^{\circ} \mathrm{C}$, their populations may possibly be able to expand or contract in accompaniment with the ecosystems where they occur (i.e. temperate forest and arid tropical scrub).

Effect of temperature on the germination rate $(G R)$ and the saturation rate $(S R)$. Both taxa registered a high GR: 3.4 seeds/day for M. aculeaticarpa var. aculeaticarpa $\left(25^{\circ} \mathrm{C}\right)$, and 6.6 seeds/day for M. luisana $\left(25-30{ }^{\circ} \mathrm{C}\right)$. Although, Carvalho and Nakagawa (2000) suggested that higher temperatures made seeds germinate faster due to an increase in water absorption speed and metabolic reactions. However, in the case of M. aculeaticarpa var. aculeaticarpa, when temperature was above $25^{\circ} \mathrm{C}$, the number of germinated seeds decreased daily; although, the GR increased at $45^{\circ} \mathrm{C}$. According to Baskin et al. (2000), this behavior may be the result of a temperature pulse that breaks the physiological dormancy.

Furthermore, when studying Mimosa hostilis (C.Mart.) Benth. (= Mimosa tenuiflora), De Souza-Araújo and De Castro-Andrade (1983) reported that the GR of scarified seeds showed a direct relationship with the PG, and these results are consistent with the results presented here.

The unscarified seeds of both Mimosa taxa had a GR of 0-0.45 seed/day. The highest value was achieved at $45^{\circ} \mathrm{C}$ for M. aculeaticarpa var. aculeaticarpa, and $20-25{ }^{\circ} \mathrm{C}$ for M. luisana.

Regarding the SR, both Mimosa taxa studied required one to two days to germinate at $25^{\circ} \mathrm{C}$, after sowing, reaching a high germination percentages; whereas, the number of days for seed germination increases at temperatures under $25^{\circ} \mathrm{C}$, due to a decrease in seed metabolism (Amaral and Paulilo, 1992). The study carried out by Pavón et al. (2011) on the germination of scarified seeds of M. aculeaticarpa var. biuncifera, confirmed the inverse relationship between GR and SR: while GR increased, SR decreased. However, this inverse relationship was not found when comparing unscarified seeds, where no significant differences were found neither among temperatures nor species.

Finally, if part of the success of a plant species is focused on its tolerance to the temperature factor, the overall results suggest that both Mimosa taxa may be able to succeed under different thermal scenarios. However, more studies are needed to understand how other climatic factors, such as different levels of precipitation and $\mathrm{CO}_{2}$ concentrations, may affect the seed germination behavior of plant species.

\section{Conclusions}

Seeds of Mimosa, like those of other legumes, have a hard and impermeable coat. To germinate, these seeds require scarification, and mechanical scarification is the best method, as neither the embryo axis nor the seedling is damaged. A comparison between healthy seeds and those prayed by bruchids is also relevant, since these insects are considered natural controls of Mimosa species populations.

Our hypothesis was confirmed: seeds of the two Mimosa taxa studied germinated according to the typical temperatures to their habitats, and both taxa showed tolerance to a wide thermal scenario. Furthermore, in this study, because seeds of both Mimosa taxa are capable to germinate under a wide range of temperatures, their populations may possibly be able to expand or contract in accompaniment with the ecosystems where they occur.

Currently, both Mimosa taxa may be used in ecological restoration programs. As Mexican native taxa, they favor successional processes leading to the restoration of their original ecosystems, respectively. We propose that: $(i)$ In temperate forests (Mexican mesic ecosystems), M. aculeaticarpa var. aculeaticarpa would restore environments where the temperature is never below $5{ }^{\circ} \mathrm{C}$ or above $45^{\circ} \mathrm{C}$, and (ii) In the arid tropical scrub (dry ecosystem), M. luisana seeds would germinate in a wider range of temperatures, suggesting that this narrow endemic species is a good option for the restoration of the semi-arid ecosystem at the Valley of Tehuacán-Cuicatlán, Mexico.

\section{Acknowledgements}

S. A. Montaño-Arias wishes to thank the Consejo Nacional de Ciencia y Tecnología (CONACyT)-México (228993/211528) for the grant to pursue a doctoral degree in the Doctorado en Ciencias Biológicas y de la Salud, Universidad Autónoma Metropolitana. The authors wish to express their appreciation to Jesús Romero-Nápoles, Instituto de Fitosanidad, Colegio de Postgraduados, Campus Montecillo, for determining bruchid specimens (Insecta, Coleoptera), and to Jennifer Bain, Instituto de Biología, UNAM, for the technical revision of the English version. We also thank the anonymous reviewers who improved our manuscript. 


\section{Literature cited}

Amaral L.I.V. and Paulilo M.T.S. 1992. Efeito da luz, temperatura, regulador de crescimento e nitrato de potássio na germinação de Miconia cinnamomifolia Naudim. Insula 21:59-86.

Auld T.D. 1996. Ecology of the Fabaceae in the Sydney region: fire, ants and the soil seedbank. Cunninghamia 4:531-551.

Baraza E. and Valiente-Banuet A. 2008. Seed dispersal by domestic goats in a semiarid thornshrub of Mexico. Journal of Arid Environments 72:1973-1976.

Barneby, R.C. 1991. Sensitivae Censitae. A description of the genus Mimosa L. (Mimosaceae) in the New World. Memoirs of the New York Botanical Garden 65:1-835.

Baskin C.C. 2003. Breaking physical dormancy in seeds - focusing on the lens. New Phytologist 158:229-232.

Baskin J.M., Baskin C.C. and Li X. 2000. Taxonomy, ecology, and evolution of physical dormancy in seeds. Plant Species Biology 15:139-152.

Baskin J.M., Nan X. and Baskin C.C. 1998. A comparative study of seed dormancy and germination in an annual and a perennial species of Senna (Fabaceae). Seed Science Research 8:501-512.

Bewley J.D. and Black M. 1994. Seeds: physiology of development and germination. Springer, New York.

Camargo-Ricalde S.L. and Grether R. 1998. Germinación, dispersión y establecimiento de plántulas de Mimosa tenuiflora (Leguminosae) en México. Revista de Biología Tropical 46:1-12.

Camargo-Ricalde S.L. 2000. Descripción, distribución, anatomía, composición química y usos de Mimosa tenuiflora (FabaceaeMimosoideae) en México. Revista de Biología Tropical 48:939954.

Camargo-Ricalde S.L., Grether R., Martínez-Bernal A., GarcíaGarcía V. and Barrios-del-Rosal S. 2001. Especies útiles del género Mimosa (Fabaceae-Mimosoideae) en México. Boletín de la Sociedad Botánica de México 68:33-44.

Camargo-Ricalde S.L., Dhillion S.S. and Grether R. 2002. Community structure of endemic Mimosa species and environmental heterogeneity in a semi-arid Mexican valley. Journal of Vegetation Science 13:697-704.

Camargo-Ricalde S.L. and Dhillion S.S. 2003. Endemic Mimosa species can serve as mycorrhizal "resource islands" within semiarid communities of the Tehuacán-Cuicatlán Valley, Mexico. Mycorrhiza 13:129-136.

Camargo-Ricalde S.L., Dhillion S.S. and García-García V. 2004. Phenology, and seed production and germination of seven endemic Mimosa species (Fabaceae- Mimosoideae) of the Tehuacán-Cuicatlán Valley, Mexico. Journal of Arid Environments 58:423-437.

Camargo-Ricalde S.L., Reyes-Jaramillo I. and Montaño N.M. 2010a. Forestry insularity effect of four Mimosa L. species (Leguminosae-Mimosoideae) on soil nutrients of a Mexican semiarid ecosystem. Agroforestry Systems 80:385-397.

Camargo-Ricalde S.L., Montaño N.M., Reyes-Jaramillo I., Jiménez-González C. and Dhillion S.S. 2010b. Effect of mycorrhizae on seedlings of six endemic Mimosa L. species (Leguminosae-Mimosoideae) from the semi-arid Tehuacán-Cuicatlán Valley, Mexico. Trees 24:67-78.

Carvalho N.M. and Nakagawa J. 2000. Sementes: ciência, tecnologia e produção. 4. ed. Jaboticabal: Funep.

Cavalcante A.M. and Perez S.C.J.A. 1995. Efeitos da temperatura sobre a germinação de sementes de Leucaena leucocephala
(Lam.) de Wit. Revista Brasileira de Sementes 17:1-8.

Chauhan B.S. and Johnson D.E. 2008. Seed germination and seedling emergence of giant sensitive plant (Mimosa invisa). Weed Science 56:244-248.

Creager R.A. 1992. Seed germination, physical and chemical control of catclaw mimosa (Mimosa pigra var. pigra). Weed Technology 6:884-891.

Cruz-Medina D. and Orozco-Almanza S. 2010. Germinación de ocho especies de la familia Fabaceae, bajo diferentes regímenes de temperatura. VII Simposio Internacional sobre la flora silvestre en zonas áridas, Universidad de Sonora, Hermosillo, Sonora, México Trabajo en extenso: 197-215 pp.

D’Aubeterre R., Principal J. and García J. 2002. Efecto de diferentes métodos de escarificación sobre la germinación de tres especies del género Prosopis. Revista Científica 12:575-577.

De Souza-Araújo M. and De Castro-Andrade G. 1983. Métodos para superar a dormência tegumentar em sementes de Juremapreta (Mimosa hostilis Benth.). Boletim de Pesquisa Florestal 6/7:26-32.

Dhillion S.S., Aguilar-Støen M. and Camargo-Ricalde S.L. 2004. Integrative ecological restoration and local involvement in the Tehuacán-Cuicatlán Valley, Mexico. Environmental Conservation 13:1-3.

Enríquez-Peña E., Suzán-Azpiri H. and Malda-Barrera G. 2004. Viabilidad y germinación de semillas de Taxodium mucronatum (Ten.) en el estado de Querétaro, México. Agrociencia 38:357-381.

Ferreira A.G., Lipp-Joao K.H. and Heuser E.D. 1992. Efeitos de escarificaçao sobre a germinaçao e do $\mathrm{pH}$ no crescimento de Acacia bonariensis Gill e Mimosa bimucronata (DC.) Kuntze. Revista Brasileira de Fisiologia Vegetal 4:63-65.

Fontúrbel R.F. 2002. Rol de la coevolución planta-insecto en la evolución de las flores cíclicas en las angiospermas. Ciencia Abierta 17:1-11.

Giordani L. 2008. The role of goats in germination and dispersal of Mimosa luisana Brandegee (Leguminosae-Mimosoideae) seeds in the Tehuacán-Cuicatlán valley, Puebla State, Mexico. Master Thesis, Norwegian University of life Sciences, Norway, 24 pp.

González-Castañeda J., Angoa-Pérez M.V., Frías-Hernández J.T., Olalde-Portugal V., Flores-Ancira E., Terrones-Rincón T.R., Van Cleemput O. and Dendooven L. 2004. Germination of seeds of huisache (Acacia schaffneri) and catclaw (Mimosa monancistra) as affected by sulphuric acid and mechanical scarification and subsequent growth and survival in a greenhouse and field experiment. Seed Science and Technology 32:727-738.

Grether R., Camargo-Ricalde S.L. and Martínez-Bernal A. 1996. Especies del género Mimosa (Leguminosae) presentes en México. Boletín de la Sociedad Botánica de México 58:149-152.

Hendricks S.B. and Taylorson B. 1976. Variation in germination and amino acid leakage of seeds with temperature related to membrane phase change. Plant Physiology 58:7-11.

Hintze J. 2001. NCSS 2001. NCSS, LLC. Kaysville, Utah, USA. www.ncss.com.

Gehan-Jayasuriya G.M., Wijetunga A.S.T.B., Baskin J.M. and Baskin C.C. 2013. Seed dormancy and storage behavior in tropical Fabaceae: a study of 100 species from Sri Lanka. Seed Science Research 23:257-269.

Leal L. and Biondi D. 2007. Comportamento germinativo de sementes de Mimosa dolens Vell. Publicatio UEPG: Ciências Ex- 
atas e da Terra, Agrárias e Engenharias 13:37-43.

Lonsdale W. M. 1993. Losses from the seed bank of Mimosa pigra: soil micro-organisms vs. temperature fluctuations. Journal of Applied Ecology 30:654-660.

Lonsdale W.M. 1999. Global patterns of plant invasions and the concept of invasibility. Ecology 80:1522-1536.

Lopez J., Devesa J.A., Ruiz T. and Ortega-Olivencia A. 1999. Seed germination in Genisteae (Fabaceae) from South-West Spain. Phyton 39:107-129.

Martínez-Pérez G., Orozco-Segovia A. and Martorell C. 2006. Efectividad de algunos tratamientos pre-germinativos para ocho especies leñosas de la Mixteca Alta Oaxaqueña con características relevantes para la restauración. Boletín de la Sociedad Botánica de México 79:9-20.

Matilla A. 2004. Ecofisiología de la germinación de semillas. In: Sánchez A., Reigosa-Roger M.J. y Pedroi-Bonjoch N. La ecofisiología Vegetal: Una ciencia de síntesis. pp. 901-922. Thomson-Paraninfo, España.

Moreno-Calles A.I. and Casas A. 2010. Agroforestry systems: restoration of semiarid zones in the Tehuacán Valley, Central Mexico. Ecological Restoration 28:361-368.

Moreno-Casasola P. 1973. Estudio sobre viabilidad y latencia de semillas de árboles tropicales. Tesis de Licenciatura, Facultad de Ciencias, Universidad Nacional Autónoma de México, México, D.F. 78 pp.

Olff H., Pegtel D.M., Van Groenendael J.M. and Bakker J.P. 1994. Germination strategies during grassland succession. Journal of Ecology 82:69-77.

Orozco-Almanza M. S., Ponce de León-García L., Grether R. and García-Moya E. 2003. Germination of four species of the genus Mimosa (Leguminosae) in a semi-arid zone of Central Mexico. Journal of Arid Environments 55:75-92.

Parmesan C. and Yohe G. 2003. A globally coherent fingerprint of climate change impacts across natural systems. Nature 421:37-42.

Parra G.P. 1984. Estudio de la morfología externa de plántulas de Calliandra gracilis, Mimosa albida, Mimosa arenosa, Mimosa camporum y Mimosa tenuiflora. Revista de la Facultad de Agronomía (Maracay) 13:311-350.

Pavón N.P., Ballato-Santos J. and Pérez-Pérez C. 2011. Germinación y establecimiento de Mimosa aculeaticarpa var. biuncifera (Fabaceae-Mimosoideae). Revista Mexicana de Biodiversidad 82:653-661.

Piedrahita-Cardona E. 1997. Germinación de semillas de Jacaranda copaia bajo condiciones contrastantes de luz. Crónica forestal y del medio ambiente 12:1-4.

Piedrahita-Cardona E. 1998. Aumento del vigor en semillas de Pinus patula (Schlecht. \& Cham.) por el efecto de osmoacondicionamiento. Crónica forestal y del medio ambiente 13:1-21.

Rivera-Aguilar V., Godínez-Álvarez H., Manuell-Cacheux I. and Rodríguez-Zaragoza S. 2005. Physical effects of biological soil crusts on seed germination of two desert plants under laboratory conditions. Journal of Arid Environments 63:344-352.

Romero-Nápoles J., Grether R., Camargo-Ricalde S.L. and Johnson C.D. 2005. Método para la evaluación de daño de semillas por brúquidos (Insecta, Coleoptera), en el campo con nuevos registros de hospederos y distribución para el grupo. Entomología Mexicana 4:107-111.

Silveira F.A.O. and Fernandes G.W. 2006. Effect of light, temperature and scarification on the germination of Mimosa foliolosa (Leguminosae) seeds. Seed Science and Technology 34:585592.

Simon M.F., Grether R., de Queiroz L.P., Särkinen T.E., Dutra V.F. and Hughes C.E. 2011. The evolutionary history of Mimosa (Leguminosae): towards a phylogeny of the sensitive plants. American Journal of Botany 78:1201-1221.

Skogen K.A., Senack L. and Holsinger K.E. 2010. Dormancy, small seed size and low germination rates contribute to low recruitment in Desmodium cuspidatum (Fabaceae). Journal of the Torrey Botanical Society 137:355-365.

Sokal R.R. and Rohlf F.J. 1995. Biometry. W.H. Freeman, New York.

Takakura K. 2002. The specialist seed predator Bruchidius dorsalis (Coleóptera: Bruchidae) plays a crucial role in the seed germination of its host plant, Gleditsia japonica (Leguminosae). Functional Ecology 16:252-257.

Taylor G.B. 2005. Hardseededness in Mediterranean annual pasture legumes in Australia. Australian Journal of Agricultural Research 56: 645-661.

Ursulino-Alves E., Cesar P.R., Pereira O.A., Alcântara B.R. and Araújo D.E. 2002. Germinação de sementes de Mimosa caesalpiniaefolia Benth. em diferentes substratos e temperaturas. Revista Brasileira de Sementes 24:169-178.

Valiente-Banuet A. and Ezcurra E. 1991. Shade as a cause of the association between the cactus Neobuxbaumia tetetzo and the nurse shrub Mimosa luisana. Journal of Ecology 79:961-971.

Valiente-Banuet A., Vite F. and Zavala-Hurtado J.A. 1991. Interaction between the cactus Neobuxbaumia tetetzo and the nurse shrub Mimosa luisana. Journal of Vegetation Science 2:11-14.

van Assche J.A., Debucquoy K.L.A. and Rommens W.A.F. 2003. Seasonal cycles in the germination capacity of buried seeds of some Leguminosae (Fabaceae). New Phytologist 158:315-323.

van Klinken R.D. and Flack L. 2005. Wet heat as a mechanism for dormancy release and germination of seeds with physical dormancy. Weed Science 53:663-669.

van Klinken R.D. and Goulier J-B. 2013. Habitat-specific seed dormancy-release mechanisms in four legume species. Seed Science Research 23:181-188.

Venier P., Funes, G. and Carrizo-García C. 2012. Physical dormancy and histological features of seeds of five Acacia species (Fabaceae) from xerophytic forests in central Argentina. Flora-Morphology, Distribution, Functional Ecology of Plants 207:39-46.

Weng J-H. and Hsu F-H. 2006. Variation of germination response to temperature in Formosan lily (Lilium formosanum Wall.) collected from different latitudes and elevations in Taiwan. Plant Production Science 9:281-286.

Westoby M., Jurado E. and Leishman M. 1992. Comparative evolutionary ecology of seed size. Trends in Ecology and Evolution 7:368-372.

Received: March 19th, 2014

Accepted: August 6th, 2014 